\title{
Correction to: Reconsidering Different Visions of Scientific Literacy and Science Education Based on the Concept of Bildung
}

Jesper Sjöström and Ingo Eilks

\section{Correction to:}

Chapter 4 in: Y.J. Dori et al. (eds.), Cognition, Metacognition, and Culture in STEM Education, Innovations in Science Education and Technology 24, https://doi.org/10.1007/978-3-319-66659-4_4

Chapter 4 was previously published non-open access. It has now been changed to open access under a CC BY 4.0 license and the copyright holder has been updated to "The Author(s)." 